\title{
Upaya Meningkatkan Hasil Belajar Tematik Materi Penjumlahan Puluhan Menggunakan Metode Permainan Media Ular Tangga
}

\author{
Puji Kurniati1 $^{*}$, Mei Fita Asri Untari² ${ }^{2}$ Joko Sulianto ${ }^{3}$ \\ 1,2,3 Universitas PGRI Semarang, Indonesia
}

A R T I C L E I N F O

Article history:

Received 19 August 2020

Received in revised form

30 September 2020

Accepted 10 October 2020

Available online 29

November 2020

\section{Kata Kunci: \\ Penjumlahan Puluhan, ular tangga}

Keywords:

Sums Tens, ladder snakes

\begin{abstract}
A B S T R A K
Tujuan penelitian ini adalah untuk menganalisis peningkatan hasil belajar siswa menggukan permaian ular tangga. Jenis penelitian ini adalah penelitian tindakan. Subjek penelitian yang berjumlah 30 orang. Data diperoleh melalui wawancara dan observasi. Data yang telah dikumpulkan (data mentah) kemudian diolah, pengolahan data dimaksudkan sebagai suatu proses untuk memperoleh data ringkasan dari data mentah dengan menggunakan cara atau rumus tertentu. Data ringkasan yang diperoleh dari pengolahan data itu dapat berupa jumlah (total), rata-rata (mean), persentase (persentage), dan sebagainya. Hasil penelitian menunjukkan bahwa Hasil tes awal sebelum diberikan tindakan dengan menggunakan media ular tangga diperoleh nilai ratarata siswa yaitu 69 dengan nilai presentase ketuntasan klasikal yaitu
\end{abstract} $40 \%$ atau sebanyak 12 orang siswa sedangkan 18 orang siswa lainnya belum/ tidak tuntas. 2) Penerapan media ular tangga dapat meningkatkan pemahaman siswa karena diberikan media secara riil dan biasa dimainkan oleh siswa sehingga memicu siswa dalam pemahaman materi penjumlahan bilangan. Dan Hasil belajar siswa setelah diberikan tindakn dengan media ular tangga semakin meningkat dari sebelum tindakan. Pada tindakan I diperoleh nilai rata-rata 83,43 dengan presentase ketuntasan klasikal yaitu $86,67 \%$ atau sebanyak 26 orang siswa yang sudah tuntas belajar. Berdasarkan hasil analisis data, dapat disimpulkan bahwa menggunakan media ular tangga dapat meningkatkan hasil belajar siswa kelas I.

\section{A B S T R A C T}

The purpose of this study was to analyze the increase in student learning outcomes using the game of snakes and ladders. This type of research is action research. The research subjects were 30 people. Data obtained through interviews and observations. The data that has been collected (raw data) is then processed, data processing is intended as a process to obtain summary data from raw data using certain methods or formulas. Summary data obtained from data processing can be in the form of a total (total), average (mean), percentage (percentage), and so on. The results showed that the results of the initial test before being given the action using snake and ladder media, the average score of the students was 69 with the classical completeness percentage value of $40 \%$ or as many as 12 students while the other 18 students had not / did not complete. 2) The application of snake and ladder media can improve students' understanding because it is given real media and is usually played by students so that it triggers students to understand the sum of numbers material. And student learning outcomes after being given follow-up with snake and ladder media increased from before the action. In action I obtained an average value of 83.43 with a percentage of classical completeness of $86.67 \%$ or as many as 26 students who have completed learning. Based on the results of data analysis, it can be concluded that using snake and ladder media can improve student learning outcomes in first gradel. 


\section{Pendahuluan}

Melalui proses pendidikan suatu bangsa berusaha untuk mencapai kemajuan-kemajuan dalam berbagai bidang kehidupannya, baik dalam bidang ekonomi, sosial, politik, ilmu pengetahuan, teknologi dan dalam bidang-bidang kehidupan budaya lainnya. Oleh sebab itu pendidikan harus ditangani secara serius oleh pendidik maupun pemerintah. Karena melalui pendidikan suatu bangsa dapat mencapai tujuan-tujuan yang direncanakan. Adapun tujuan pendidikan nasional yang ingin dicapai oleh bangsa Indonesia tercantum dalam UU No. 20 tahun 2003 tentang pendidikan nasional pada pasal III, yang menyatakan bahwa: "Pendidikan nasional berfungsi mengembangkan kemampuan dan membentuk watak serta peradaban bangsa yang bermartabat dalam rangka mencerdaskan bangsa. Pendidikan nasional juga bertujuan untuk berkembangnya potensi peserta didik agar menjadi manusia yang beriman dan bertakwa kepada Tuhan Yang Maha Esa, berakhlak mulia, sehat, berilmu, cakap, kreatif dan menjadi warga negara yang demokratis, serta tanggung jawab (Muklis, 2012).

Rendahnya mutu pendidikan di Indonesia bukan hanya pada level perguruan tinggi, melainkan pada level yang ada di bawahnya sampai pada level yang paling rendah. Tuntutan terhadap lulusan dan layanan lembaga pendidikan yang bermutu semakin mendesak karena semakin ketatnya persaingan dalam lapangan kerja. Hal ini menjadikan persaingan antar lembaga penyelenggara pendidikan dan pasar kerja semakin berat. Peningkatan mutu pendidikan menjadi hal yang perlu ditingkatkan untuk mengantisipasi perubahan-perubahan yang begitu cepat serta tantangan yang semakin besar dan kompleks (Miftachurrahman \& Atika, 2018). Pemerintah telah melaksanakan berbagai proyek pendidikan, di antaranya pengembangan kurikulum, Manajemen Peningkatan Mutu Berbasis Sekolah (MPMBS), peningkatan layanan dan koleksi perpustakaan, Bantuan Meningkatkan Manajemen Mutu (BOMM), Bantuan Imbal Swadaya (BIS), Pengadaan Buku Paket, Peningkatan Mutu Guru, Dana Bantuan Langsung (DBL), Bantuan Operasional Sekolah (BOS), dan Bantuan Khusus Murid (BKM). Selain itu, pemerintah juga terus berusaha menanamkan kesadaran pendidikan terhadap masyarakat, sehingga masyarakat berpartisipasi dalam meningkatkan mutu pendidikan (Djihadah, 2020). Bahkan kurikulum yang awalnya KTSP diubah memnjadi kurikulum K-13.

Kurikulum 2013 adalah kurikulum yang berbasis kompetensi.Dimana di dalamnya dirumuskan secara terpadu kompetensi sikap, pengetahuan, dan keterampilan yang harus dikuasai peserta didik.Adapun untuk lebih memudahkan pencapaian kompetensi yang dirumuskan maka dipilih pembelajaran tematik sebagai basis dalam pembelajaran.Pembelajaran tematik merupakan pendekatan pembelajaran yang didasarkan pada pemilihan tema yang sesuai dengan dunia anak sehingga menarik minat belajarnya. Adanya kesesuaian antara materi pembelajaran dengan dunia nyata dan minat belajar anak dapat mendorong anak untuk terlibat aktif dan mendapatkan kebermaknaan dalam proses belajar.

Hakekat pembelajaran tematik menurut (Trianto, 2010) dimaknai sebagai pembelajaran yang dirancang berdasarkan tema-tema tertentu. Pembelajaran tematik merupakan suatu pendekatan dalam pembelajaran yang secara sengaja mengaitkan beberapa aspek baik dalam intra mata pelajaran maupun antar mata pelajaran. Pembelajaran tematik tidak semata-mata belajar medorong siswa untuk mengetahui (learning to know), tetapi belajar juga untuk melakukan (learning to do), untuk menjadi (learning to be) dan untuk hidup bersama (learning to live together) (Prastowo, 2013), proses pembelajaran tematik dikaitkan dengan ekperimen dan penemuan tidak hanya terus menerus dengan latihan atau menghafal, sehingga pembelajaran yang sesungguhnya akan lebih hidup, menyenangkan, dan tidak membosankan. Selanjutnya dapat ditegaskan bahwa dalam tindakan pembelajaran, sekolah harus memberikan pendidikan secara menyeluruh pada siswa, pembelajaran dipusatkan kepada siswa tidak hanya dipusatkan pada materi atau dipusatkan pada guru, karena kepentingan dan kematangan dalam perkembangan anak terbatas. Bruner (Winataputra, 2009) mengatakan bahwa belajar merupakan suara proses aktif yang memungkinkan manusia untuk menemukan hal-hal baru di luar informasi yang diberikan kepada dirinya. Proses belajar akan berlangsung secara optimal jika proses pembelajaran diawali dengan tahap pembelajaran pengetahuan secara aktif, dengan menggunakan benda konkret atau situasi yang nyata, dilanjutkan dengan tahap ikonik yaitu tahap pembelajaran pengetahuan diwujudkan dalam bentu bayangan, gambar, atau diagram, dan diteruskan dengan tahap simbolik yaitu tahap pembelajaran pengetahuan yang diwujudkan dalam bentuk simbol-simbol abstrak. Serta, proses pembelajaran akan berlangsung optimal bila siswa memperoleh sejumlah kegiatan mengolah bahan, mengerjakan soal, membuat kesimpulan, dan merumuskan suatu rumusan dengan kata-kata sendiri, dan secara kooperatif dengan siswa lain, dalam suasana lingkungan yang menyenangkan, dan dalam bimbingan guru. Keaktifan siswa merupakan faktor utama dalam proses belajar dan keterampilan proses merupakan kemampuan siswa dalam memperoleh informasi, struktur pengetahuan, dan perkembangan dirinya, maka keaktifan dan keterampilan proses siswa pada penelitian ini diamati. 
Oleh karena itu pembelajaran tematik di sekolah dasar sangat perlu untuk diaksanakan dan diterapkan kepada siswa dan pentingnya pemahaman guru tentang pembelajaran tematik di sekolah dasar (Prastowo, 2013). Beberapa karakteristik pembelajaran tematik yang menjadi pembeda dengan pembelajaran yang lain adalah sebagaimana berikut: (1) Berpusat pada peserta didik. Maksudnya, pembelajaran berpusat pada siswa, hal ini sesuai dengan pendekatan belajar modern yang menempatkan siswa sebagai subjek belajar, sedangkanposisi guru sebagai fasilitator, (2) Memberikan pengalaman langsung pada peserta didik (direct experiences); dengan pengalaman langsung, siswa dihadapkan pada sesuatu yang nyata sebagai dasar untuk memehami hal-hal yang lebih abstrak, (3) Pemisahan antara mata pelajaran tidak begitu nyata dan jelas maksudnya, fokus pembelajaran diarahkan kepada pembahasan tema-tema yang paling dekat berkaitan dengan kehidupan siswa, (4) Menyajikan suatu konsep dari berbagai mata pelajaran dalam suatu proses pembelajaran.

Dengan hal ini siswa diharapkan mampu memahami konsep-konsep tersebut secara utuh serta untuk membantu permasalahan siswadalam kehidupan sehari-hari, (5) Fleksibel atau luwes, artinya bahan ajar dalam satu mata pelajaran dapat dikaitkan dengan mata pelajaran yang lainnya, bahkan dapat dikaitkan dengan lingkungan tempat sekolah dan siswa berada, (6) Hasil pembelajaran sesuai dengan minat dan kebutuhan siswa, sebab siswa diberikan kesempatan untuk mengoptimalkan potensinya sesuai dengan keinginannya, (7) Menggunakan prinsip belajar sambil bermain, sehingga proses pembelajaran terasa lebih menyenangkan (Frasandy, 2017; Suheli, 2018). Pembelajaran tematik juga memiliki ramburambu yang harus diperhatikan yakni tidak semua pelajaran harus dipadukan, kompetensi dasar yang tidak dapat dipadukan, tidak boleh dipaksakan untuk dipadukan, melainkan disajikan secara tersendiri, kompetensi dasar yang tidak tercakup pada tema tertentu harus tetap diajarkan dengan cara melalui tema lain atau secara tersendiri, kegiatan pembelajaran ditekankan pada kemampuan membaca, menulis, berhitung, dan penanaman nilai-nilai moral, tema-tema yang dipilih disesuaikan dengan karakteristik (siswa, lingkungan, dan daerah setempat).

Pembelajaran tematik merupakan suatu cara dalam menerapkan pembelajaran penjasorkes di sekolah dasar. Pembelajaran tematik meliputi berbagai mata pelajaran yang disajikan secara terpadu dengan tema sebagai pemersatunya. Upaya untuk menyatukan berbagai kompetensi dasar dariberbagai mata pelajaran, perlu adanya kajian yang mendalam dengan mengacu pada standar kompetensi lulusan. Pembelajaran tematik disajikan secara fleksibel, tidak dipaksakan, saling melengkapi, saling terkait, dan tidak terpisahkan. Didalam pelaksanaan pembelajaran tematik guru diharuskan memiliki kompetensi yang mumpuni sesuai dengan bidang keahlian masing-masing dari mata pelajaran yang diajarkan oleh guru tersebut.

Guru sekolah dasar hendaknya dapat memahami konsep pembelajaran tematik yang akan dilaksanakan. Pengelolaan pembelajaran tematik (perencanaan, pelaksanaan, dan evaluasi) juga harus diperhatikan oleh guru sekolah dasar (Hidayati, 2016; Samsudin, 2008). Kelebihan dari pembelajaran tematik yaitu: (1) Memberikan pengalaman dan kegiatan belajar anak relevan dengan tingkat perkembangannya, (2) Kegiatan yang dipilih sesuai dengan minat dan kebutuhan anak, (3) Kegiatan belajar bermakna bagi anak sehingga hasilnya dapat bertahan lama, (4) Keterampilan berpikir anak berkembang dalam proses pembelajaran terpadu Keterampilan berpikir anak berkembang dalam proses pembelajaran terpadu, (5) Kegiatan belajar mengajar bersifat pragmatis sesuai lingkungan anak, (6) Keterampilan sosial anak berkembang dalam proses pembelajaran terpadu. Pembelajaran tematik akan memotivasi peserta didik untuk belajar karena pembelajaran tematik merupakan pembelajaran integrasi yang relevan dengan kebutuhan dan perkembangan peserta didik serta mengikuti prinsip-prinsip kontruktivisme sehingga peserta didik dapat membangun pengetahuannya sendiri melalui pengalaman dan lingkungan (Badariah et al., 2019; Prasetyo \& Prasojo, 2016).

Pembelajaran tematik dalam penerapannya membutuhkan metode pembelajaran, salah satu metode yang dipilih adalah metode permaian media ular tangga. Media pembelajaran permainan ular tangga merupakan media pembelajaran yang dikembangkan berdasarkan permainan tradisional permainan ular tangga disesuaikan dengan karakteristik siswa dengan tujuan untuk mencapai tujuan pembelajaran sebagai pengantar informasi bagi siswa dan dapat meningkatkan kemampuan bersosialisasi bagi peserta didik (Afandi, 2015; Nisa et al., 2015). Selain itu, permainan ular tangga juga dapat menghibur anak-anak dengan cara yang positif dan sangat interaktif (Prameswari, 2018). Kelebihan permainan ular tangga ialah siswa dapat belajar sambil bermain, siswa tidak belajar sendiri, melainkan harus berkelompok, memudahkan siswa belajar karena dibantu dengan gambar yang ada dalam permainan ular tangga, dan tidak memerlukan biaya mahal dalam membuat media pembelajaran permainan ular tangga (Yuni et al., 2019; Supranoto, 2018; Afandi, 2015)

Penelitian yang dilakukan oleh (Afifah \& Hartatik, 2019) menyatakan bahwa ada pengaruh penggunaan media permainan ular tangga terhadap motivasi belajar siswa. Kemudian penelitian yang dilakukan oleh (Prameswari, 2018) menyatakan bahwa terjadi ketuntasan belajar dan mengalami 
peningkatan hasil belajar kognitif mahasiswa STKIP Bina Insan Mandiri materi Strategi Pembelajaran menggunakan media ular tangga. Penelitian lain juga dilakukan oleh (Nisa et al., 2015) menyatakan bahwa media permainan ular tangga berpengaruh terhadap hasil belajar kognitif siswa SMA Negeri 99 Jakarta. Berdasarkan jabaran tersebut dapat dikatakan bahwa pembelajaran tematik dan media ular tangga berdampak positif, berdasarkan kelebihan pembelajaran tersebut, maka dirumuskanlah sebuah tujuan tindakan yaitu tujuan penelitin ini adalaha untuk menganalisis peningkatan hasil belajar siiswa menggunakan permaian ular tangga.

\section{Metode}

Pendekatan penelitian yang digunakan peneliti untuk memperoleh data sekunder adalah pendekatan penelitian tindakan kelas. Alasan digunakannya pendekatan penelitian tindakan kelas adalah karena peneliti ingin mengetahui perkembangan hasil belajar siswa dengan media ular tangga dan tanpa menggunakan media. Penelitian dilaksanakan dan dilakukan secara daring dengan menggunakan grup whatsapp karena terkendalam keadaan yang belum memungkinkan untuk pembelajaran didalam kelas, dan juga mematuhi protokol kesehatan Covid 19. Yang beralamat di Jl Soekarno Hatta No. 5, Pedurungan Tengah, Kec. Pedurungan, Kota Semarang, Jawa Tengah (50192).

Subjek dalam penelitian ini adalah siswa kelas I SDN Pedurungan Tengah 02 Semarang. Sedangkan objek dalam penelitian ini adalah hasil belajar tematik materi penjumlahan puluhan menggunakan media ular tangga. Pada penelitian ini dilakukan di SDN Pedurungan Tengah 02 Semarang yang terletak di Jl. Soekarno Hatta No. 5, Pedurungan Tengah, Kec. Pedurungan, Kota Semarang. Yang dipimpin kepala sekolah Ibu Daryati, S.Pd., M.Pd. Jumlah guru yang mengajar sebanyak 18 orang terdiri dari 13 perempuan dan 5 laki-laki, dan terdiri dari 14 rombel/ kelas.

Peneliti menggunakan peneliti sendiri sebagai sebagai instrument utama dalam penelitian dengan mempergunakan alat bantu berupa pedoman observasi dan pedoman wawancara. Pedoman observasi digunakan sebagai alat bantu peneliti untuk memeperoleh data. Pedoman wawancara dipergunakan untuk memperoleh data dari subjek penelitian dan informan.

Pelaksanaan penelitian untuk mendapatkan data, peneliti menerapkan pembelajaran secara daring, menggunakan Whatsapp kepada peserta didik melalui perangkat Whatsapp Grup kelas 1 SDN Pedurungan Tengah 02 Semarang. Untuk pendahuluan peneliti melakukan wawancara tidak terstruktur mengenai materi yang pernah diajarkan pada materi penjumlahan puluhan. Selanjutnya memberikan soal pre test dan soal post test dengan tujuan akan diujikan pada tes siklus sehingga dapat dipertanggung jawabkan dan dianalisis. Data yang telah dikumpulkan (data mentah) kemudian diolah, pengolahan data dimaksudkan sebagai suatu proses untuk memperoleh data ringkasan dari data mentah dengan menggunakan cara atau rumus tertentu. Data ringkasan yang diperoleh dari pengolahan data itu dapat berupa jumlah (total), rata-rata (mean), persentase (persentage), dan sebagainya. Penggunaan media ular tangga pada materi penjumlahan puluhan bertujuan untuk mengetahui apakah hasil belajar dapat tercapai atau tidak.

\section{Hasil dan Pembahasan}

Data pada penelitian ini terdiri atas tes awal pada materi penjumlahan puluhan, nilai dari tes awal sebagai pengukur kemampuan awal sebelum diterapkan media ular tangga, sedangkan pada siklus I setelah diterapkan media ular tangga.

Ajaran yang digunakan guru dalam mengajar matematika di kelas adalah dengan menggunakan metode ceramah dan tanya jawab saja. Guru merasa kesulitan untuk menggunakan metode lain dikarenakan kurangnya pengetahuan guru akan metode-metode baru yang inovatif, selain itu juga guru beranggapan bahwa metode-metode tersebut hanya mempersulit dan membutuhkan persiapan yang banyak. Kurangnya penggunaan media pembelajaran dan alat peraga pun membuat pembelajaran di kelas menjadi membosankan, siswa menjadi kurang berpatisipasi aktif dalam kegiatan belajar-mengajar, kebanyakan dari siswa tersebut acuh bahkan sulit diatur dan tidak mau mendengarkan penjelasan yang sedang disampaikan oleh guru.

Hasil penelitian tindakan kelas data diperoleh dari soal pre-test dan soal post-test yang diberikan kepada siswa dalam pembelajaran pada materi penjumlahan puluhan untuk peningkatan hasil belajar pada siswa kelas 1 SDN Pedurungan Tengah 02 Semarang. Di bawah ini terlihat tabel dan gambar diagram rekapitulasi perbandingan hasil peningkatan belajar nilai siswa pada tes awal dan siklus I. 
Tabel 1. Rekapitulasi Hasil Belajar Matematika Siswa

\begin{tabular}{clcc}
\hline No & Data & Tes Awal & Tes Siklus I \\
\hline 1 & Tuntas secara individu & 9 & 26 \\
2 & Tidak tuntas secara individu & 21 & 4 \\
3 & Nilai Maksimum & 80 & 97 \\
4 & Nilai minimum & 40 & 63 \\
5 & Jumlah nilai & 2070 & 2505 \\
6 & Rata-rata & 69 & 83,5 \\
7 & Ketentuan secara klasikal & $40 \%$ & $86,67 \%$ \\
\hline
\end{tabular}

Berdasarkan tabel di atas, menunjukkan peningkatan hasil belajar matematika siswa dari pertemuan sebelumnya. Diperoleh nilai rata-rata siswa yaitu 83,5 dan telah mencapai ketuntasan belajar secara klasikal yaitu 86,67 \% atau sebanyak 26 siswa dari 30 siswa setelah menggunakan media ular tangga. Target peniliti sudah tercapai maka tindakan diberhentikan pada siklus ini.

Peningkatan hasil siklus dari parsiklus dan siklus 1 hal ini alasnya adalah adalnya media ualar tangga, dengan adanya permainan dalam proses pembelajaran akan mampu membuat siswa nyaman dalam proses pembelajaran dan tentunya dapat membuat siswa lebih aktif karena siswa senang mengikuti pembelajaran. dengan senang mengikuti pembelajaran maka hasilnya pun akan menyesauikan. Menurut (Suprijono, 2012), hasil belajar adalah polapola perbuatan, nilai-nilai, pengertian-pengertian, sikapsikap, apresiasi dan keterampilan. Selanjutnya (Supratiknya, 2012) mengemukakan bahwa hasil belajar yang menjadi objek penilaian kelas berupa kemampuan-kemampuan baru yang diperoleh siswa setelah mereka mengikuti proses belajar-mengajar tentang mata pelajaran tertentu. Dalam sistem pendidikan nasional rumusan tujuan pendidikan mengacu pada klasifikasi hasil belajar dari Bloom yang secara garis besar yaitu aspek kognitif, aspek afektif dan aspek psikomotor (Widodo, 2013). Keberhasilan belajar tidak hanya dilihat dari kemampuan siswa menyelesaikan tes yang diberikan pada akhir suatu pembelajaran, tetapi perlu memperhatikan kemampuan siswa dalam mengikuti tahap-tahap pembelajaran. Jadi kemampuan yang ditunjukkan oleh siswa selama proses pembelajaran berlangsung, perlu dipertimbangkan untuk menentukan keberhasilan belajar siswa.

Dengan adanya pembelajaran Tematik siswa akan lebih aktif karena pembalajaran ini, lebih menkakan kapada pendekatan saintifik yang menuntut siswa belajar untuk melakukan percobaan. Dengan pembelajaran seperti itu siswa kan lebih dibuat aktif mengagali penegtahuannya sendiri. Proses pembelajaran tematik dikaitkan dengan ekperimen dan penemuan tidak hanya terus menerus dengan latihan atau menghafal, sehingga pembelajaran yang sesungguhnya akan lebih hidup, menyenangkan, dan tidak membosankan. Selanjutnya dapat ditegaskan bahwa dalam tindakan pembelajaran, sekolah harus memberikan pendidikan secara menyeluruh pada siswa, pembelajaran dipusatkan kepada siswa tidak hanya dipusatkan pada materi atau dipusatkan pada guru, karena kepentingan dan kematangan dalam perkembangan anak terbatas. Bruner dalam (Winataputra, 2009) mengatakan bahwa belajar merupakan suara proses aktif yang memungkinkan manusia untuk menemukan hal-hal baru di luar informasi yang diberikan kepada dirinya. Proses belajar akan berlangsung secara optimal jika proses pembelajaran diawali dengan tahap pembelajaran pengetahuan secara aktif, dengan menggunakan benda konkret atau situasi yang nyata, dilanjutkan dengan tahap ikonik yaitu tahap pembelajaran pengetahuan diwujudkan dalam bentu bayangan, gambar, atau diagram, dan diteruskan dengan tahap simbolik yaitu tahap pembelajaran pengetahuan yang diwujudkan dalam bentuk simbol-simbol abstrak. Serta, proses pembelajaran akan berlangsung optimal bila siswa memperoleh sejumlah kegiatan mengolah bahan, mengerjakan soal, membuat kesimpulan, dan merumuskan suatu rumusan dengan kata-kata sendiri, dan secara kooperatif dengan siswa lain, dalam suasana lingkungan yang menyenangkan, dan dalam bimbingan guru. Keaktifan siswa merupakan faktor utama dalam proses belajar dan keterampilan proses merupakan kemampuan siswa dalam memperoleh informasi, struktur pengetahuan, dan perkembangan dirinya, maka keaktifan dan keterampilan proses siswa pada penelitian ini diamati.

Oleh karena itu pembelajaran tematik di sekolah dasar sangat perlu untuk diaksanakan dan diterapkan kepada siswa dan pentingnya pemahaman guru tentang pembelajaran tematik di sekolah dasar (Prastowo, 2013). Beberapa karakteristik pembelajaran tematik yang menjadi pembeda dengan pembelajaran yang lain adalah sebagaimana berikut: (1) Berpusat pada peserta didik. Maksudnya, pembelajaran berpusat pada siswa, hal ini sesuai dengan pendekatan belajar modern yang menempatkan siswa sebagai subjek belajar, sedangkanposisi guru sebagai fasilitator, (2) Memberikan pengalaman langsung pada peserta didik (direct experiences); dengan pengalaman langsung, siswa dihadapkan pada sesuatu yang nyata sebagai dasar untuk memehami hal-hal yang lebih abstrak, (3) Pemisahan antara mata pelajaran tidak begitu nyata dan jelas maksudnya, fokus pembelajaran diarahkan kepada pembahasan 
tema-tema yang paling dekat berkaitan dengan kehidupan siswa, (4) Menyajikan suatu konsep dari berbagai mata pelajaran dalam suatu proses pembelajaran.

Dengan hal ini siswa diharapkan mampu memahami konsep-konsep tersebut secara utuh serta untuk membantu permasalahan siswadalam kehidupan sehari-hari, (5) Fleksibel atau luwes, artinya bahan ajar dalam satu mata pelajaran dapat dikaitkan dengan mata pelajaran yang lainnya, bahkan dapat dikaitkan dengan lingkungan tempat sekolah dan siswa berada, (6) Hasil pembelajaran sesuai dengan minat dan kebutuhan siswa, sebab siswa diberikan kesempatan untuk mengoptimalkan potensinya sesuai dengan keinginannya, (7) Menggunakan prinsip belajar sambil bermain, sehingga proses pembelajaran terasa lebih menyenangkan (Frasandy, 2017; Suheli, 2018). Pembelajaran tematik juga memiliki ramburambu yang harus diperhatikan yakni tidak semua pelajaran harus dipadukan, kompetensi dasar yang tidak dapat dipadukan, tidak boleh dipaksakan untuk dipadukan, melainkan disajikan secara tersendiri, kompetensi dasar yang tidak tercakup pada tema tertentu harus tetap diajarkan dengan cara melalui tema lain atau secara tersendiri, kegiatan pembelajaran ditekankan pada kemampuan membaca, menulis, berhitung, dan penanaman nilai-nilai moral, tema-tema yang dipilih disesuaikan dengan karakteristik (siswa, lingkungan, dan daerah setempat). Pembelajaran tematik akan memotivasi peserta didik untuk belajar karena pembelajaran tematik merupakan pembelajaran integrasi yang relevan dengan kebutuhan dan perkembangan peserta didik serta mengikuti prinsip-prinsip kontruktivisme sehingga peserta didik dapat membangun pengetahuannya sendiri melalui pengalaman dan lingkungan (Badariah et al., 2019; Prasetyo \& Prasojo, 2016).

Penelitian yang dilakukan oleh (Amry \& Badriah, 2018) menyatakan bahwa pembelajaran tematik dapat meningkatkan keaktifan peserta didik pada kegiatan belajar mengajar di kelas II MI Ma'arif Kadipolo Salam Magelang. Kemudian penelitian yang dilakukan oleh (Firdaus \& Badriyah, 2018) menyatakan bahwa penerapan pembelajaran tematik berbasis budaya Betawi dapat meningkatkan kecerdasan logika siswa. Penelitian lain juga dilakukan oleh (Aini \& Relmasira, 2018) menyatakan bahwa pembelajaran tematik integratif berbasis kontekstual dapat meningkatkan keaktifan dan hasil belajar siswa kelas 1 SD N Salatiga 03.

Pembelajaran dengan media ular tangga akan membuat sarana pembelajaran lebih menyenangkan dan siswa tidak merasa bosan karena hanya menjawab pertanyaan atau belajaran dengan WA. Media pembelajaran permainan ular tangga merupakan media pembelajaran yang dikembangkan berdasarkan permainan tradisional permainan ular tangga disesuaikan dengan karakteristik siswa dengan tujuan untuk mencapai tujuan pembelajaran sebagai pengantar informasi bagi siswa dan dapat meningkatkan kemampuan bersosialisasi bagi peserta didik (Afandi, 2015; Nisa et al., 2015). Selain itu, permainan ular tangga juga dapat menghibur anak-anak dengan cara yang positif dan sangat interaktif (Prameswari, 2018). Kelebihan permainan ular tangga ialah siswa dapat belajar sambil bermain, siswa tidak belajar sendiri, melainkan harus berkelompok, memudahkan siswa belajar karena dibantu dengan gambar yang ada dalam permainan ular tangga, dan tidak memerlukan biaya mahal dalam membuat media pembelajaran permainan ular tangga (Yuni et al., 2019; Supranoto, 2018; Afandi, 2015).

Penelitian yang dilakukan oleh (Novita \& Sundari, 2020) menyatakan bahwa penggunaan media ular tangga digital dapat meningkatkan hasil belajar dan perubahan sikap pada materi pembelajaran I. Penelitian yang dilakukan oleh (Afifah \& Hartatik, 2019) menyatakan bahwa ada pengaruh penggunaan media permainan ular tangga terhadap motivasi belajar siswa. Kemudian penelitian yang dilakukan oleh (Prameswari, 2018) menyatakan bahwa terjadi ketuntasan belajar dan mengalami peningkatan hasil belajar kognitif mahasiswa STKIP Bina Insan Mandiri materi Strategi Pembelajaran menggunakan media ular tangga. Penelitian lain juga dilakukan oleh (Nisa et al., 2015) menyatakan bahwa media permainan ular tangga berpengaruh terhadap hasil belajar kognitif siswa SMA Negeri 99 Jakarta. Berdasarkan jabaran tersebut dapat dikatakan bahwa pembelajaran tematik dan media ular tangga berdampak positif, berdasarkan kelebihan pembelajaran tersebut, maka dirumuskanlah sebuah tujuan tindakan yaitu tujuan penelitin ini adalaha untuk menganalisis peningkatan hasil belajar siiswa menggunakan permaian ular tangga.

\section{Simpulan Dan Saran}

Penelitian Berdasarkan hasil dari tes awal dan siklus I maka dapat disimpulkan bahwa: 1) Hasil tes awal sebelum diberikan tindakan dengan menggunakan media ular tangga diperoleh nilai rata-rata siswa yaitu 69 dengan nilai presentase ketuntasan klasikal yaitu $40 \%$ atau sebanyak 12 orang siswa sedangkan 18 orang siswa lainnya belum/ tidak tuntas. 2) Penerapan media ular tangga dapat meningkatkan pemahaman siswa karena diberikan media secara riil dan biasa dimainkan oleh siswa sehingga memicu siswa dalam pemahaman materi penjumlahan bilangan. Dan Hasil belajar siswa setelah diberikan tindakn dengan media ular tangga semakin meningkat dari sebelum tindakan. Pada tindakan I diperoleh nilai rata- 
rata 83,43 dengan presentase ketuntasan klasikal yaitu $86,67 \%$ atau sebanyak 26 orang siswa yang sudah tuntas belajar. Oleh karena itu dengan menggunakan media ular tangga dapat meningkatkan hasil belajar siswa kelas 1 SDN Pedurungan Tengah 02 Semarang. Berdasarkan simpulan di atas, saran yang dari peneliti adalah Guru kelas 1 dapat menjadikan media ular tangga menjadi salah satu alternatif dalam memilih media pembelajaran pada materi penjumlahan bilangan, Siswa diharapkan belajar lebih giat serta menjadikan benda-benda riil disekitar sebagai bahan belajar, Peneliti selanjutnya yag berminat melakukan penelitian dengan menggunakan model pembelajran yang sama, disarankan untuk mengembangkan penelitian ini, serta dapat menggunakan media atau model pembelajaran yang lain pada materi materi selanjutnya.

\section{Daftar Rujukan}

Djihadah, Nuryati. 2020. Kecerdasan Emosional dan Kepemimpinan Kepala Madrasah dalam Aplikasi Penguatan Pendidikan Karakter (PPK) di Madrasah. Jurnal Pendidikan Madrasah, Volume 5, Nomor 1, Mei 2020. https://doi.org/10.14421/jpm.2020.51-01

Gandasari, Maharani Fatima. 2019. Pengembangan model pembelajaran tematik Pendidikan jasmani olahraga dan kesehatan untuk sekolah dasar . Jurnal Pendidikan Jasmani Indonesia, 15 (1), 2019. https://doi.org/10.21831/jpji.v15i1.25489

Muklis, Mohamad. 2012. Pembelajaran Tematik. Fenomena. Vol. Iv No. 1, 2012. https://doi.org/10.21093/fj.v4i1.279

Nanang Hanifah, dkk. 2009. Konsep dan Strategi Pembelajaran. Bandung: Refika Aditama.

Nurkholis. 2013. Pendidikan Dalam Upaya Memajukan Teknologi. Jurnal Kependidikan, Vol. 1 No. 1 Nopember 2013. ttps://doi.org/10.24090/jk.v1i1.530

Sutrisno. 2016. Berbagai Pendekatan Dalam Pendidikan Nilai Dan Pendidikan Kewarganegaraan . Jurnal Dimensi Pendidikan dan Pembelajaran Vol.5 Januari 2016. DOI : 10.24269/dpp.v4i1.56

Sholichah, Aas Siti. 2018. Teori-Teori Pendidikan Dalam Al-Qur'an . Jurnal Pendidikan Islam Vol.07, No. 1. http://dx.doi.org/10.30868/ei.v7i01.209

Widodo. 2013. Peningkatan Aktivitas Belajar Dan Hasil Belajar Siswa Dengan Metode Problem Based Learning Pada Siswa Kelas Viia Mts Negeri Donomulyo Kulon Progo Tahun Pelajaran 2012/2013. Jurnal Fisika Indonesia No: 49, Vol XVII, Edisi April 2013. https://doi.org/10.22146/jfi.24410

Widodo, Heri. 2015. Potret Pendidikan Di Indonesia Dan Kesiapannya Dalam Menghadapi Masyarakat Ekonomi Asia (Mea). Jurnal Cendekia Vol. 13 No. 2, Juli - Desember 2015. https://doi.org/10.21154/cendekia.v13i2.250

Winataputra, Udin. S. (2009).Teori Belajar dan Pembelajaran. Jakarta: Universitas Terbuka

Afandi, R. (2015). Pengembangan Media Pembelajaran Permainan Ular Tangga Untuk Meningkatkan Motivasi Belajar Siswa dan Hasil Belajar IPS di Sekolah Dasar. JINoP (Jurnal Inovasi Pembelajaran), 1(1), 77. https://doi.org/10.22219/jinop.v1i1.2450

Afifah, N., \& Hartatik, S. (2019). Pengaruh Media Permainan Ular Tangga terhadap Motivasi Belajar pada Pelajaran Matematika Kelas II SD Kemala Bhayangkari 1 Surabaya. MUST: Journal of Mathematics Education, Science and Technology, 4(2), 209. https://doi.org/10.30651/must.v4i2.3035

Aini, Q., \& Relmasira, S. C. (2018). Penerapan Pembelajaran Tematik Integratif Berbasis Kontekstual untuk Meningkatkan Keaktifan dan Hasil Belajar Siswa Kelas 1 SD. Sekolah Dasar: Kajian Teori Dan $\begin{array}{lrl}\text { Praktik Pendidikan, 27(2), } & \end{array}$ https://doi.org/http://dx.doi.org/10.17977/um009v27i22018p124

Amry, Z., \& Badriah, L. (2018). Pembelajaran tematik sebagai upaya meningkatkan keaktifan peserta didik. $\begin{array}{llll}\text { ELEMENTARY: } \quad \text { Islamic Teacher } & \text { 254-270. }\end{array}$ https://doi.org/10.21043/elementary.v6i2.4388

Badariah, S., Muskania, R. T., \& Mansur, M. (2019). Pembelajaran Tematik Menggunakan Media Video Scribe Pada Siswa Kelas Iv Sekolah Dasar. Elementary, 7(1). https://doi.org/http://dx.doi.org/10.21043/elementary.v7i1.4927

Firdaus, F. M., \& Badriyah, N. (2018). Penerapan Pembelajaran Tematik Berbasis Budaya Betawi untuk Meningkatkan Logical Intelligence Siswa SD Islam Taman Qur'aniyah Jakarta Selatan. Al Ibtida: 
Jurnal Pendidikan Guru MI, 5(1), 95. https://doi.org/10.24235/al.ibtida.snj.v5i1.2727

Nisa, A., Djamahar, R., \& Evriyani, D. (2015). Pengaruh Penggunaan Media Permainan Ular Tangga Terhadap Hasil Belajar Kognitif pada Materi Sistem Reproduksi Manusia. Jurnal Biosfer, 8(2), 2026. https://doi.org/https://doi.org/10.21009/biosferjpb.8-2.4

Novita, L., \& Sundari, F. S. (2020). Peningkatan Hasil Belajar Siswa Menggunakan Media Game Ular Tangga Digital. Jurnal Basicedu, 4(3), 716-724. https://doi.org/10.31004/basicedu.v4i3.428

Prameswari, N. K. (2018). Peningkatan Dalam Penggunaan Media Ular Tangga Mata Kuliah Pendidikan PKn SD Materi Strategi Pembelajaran Pada Kemampuan Kognitif Mahasiswa Semester 2 STKIP Bina Insan Mandiri Surabaya. Jurnal Bidang Pendidikan Dasar (JBPD), 2(1). https://doi.org/https://doi.org/10.21067/jbpd.v2i1.2188

Prasetyo, G., \& Prasojo, L. D. (2016). Pengembangan Adobe Flash Pada Pembelajaran Tematik-Integratif Berbasis Scientific Approach Subtema Indahnya Peninggalan Sejarah. Jurnal Prima Edukasia, 4(1), 54. https://doi.org/10.21831/jpe.v4i1.7788

Supranoto, H. (2018). Pengembangan Soal HOTS Berbasis Permainan Ular Tangga pada Mata Kuliah Telaah Ekonomi SMA. Journal of Chemical Information and Modeling, 6(1), 103-110. https://doi.org/http://dx.doi.org/10.24127/pro.v6i1.1501

Yuni, Y. A., Zulhanan, Z., \& Sodikin, S. (2019). Pengembangan Permainan Ular Tangga Bernuansa Islami Untuk Pembelajaran IPA. Indonesian Journal of Science and Mathematics Education, 2(2), 194-203. https://doi.org/10.24042/ijsme.v2i2.4343 